\title{
A Rare Pathology Mimicing Acute Appendicitis; Epiploic Appendagitis
}

Akut Apandisiti Taklit Eden Nadir Bir Patoloji; Epiploik Apandajit

\author{
Hakan Özdemir, Zehra Ünal Özdemir, Metin Şenol, Ibrahim Tayfun Şahiner
}

Ministry Of Health, Nevsehir State Hospital, General Surgery Department, Nevsehir

Yazışma Adresi / Corresponding to:

Dr. Hakan Özdemir, Nevşehir Devlet Hastanesi NEVŞEHIR - Türkiye

Tel: 05324685380 Mail: hakanzdmr@yahoo.com

Aim: Primary epiploic appendagitis (PEA) is an inflammatory disease occurs due to the torsion or spontaneous venous thrombosis of colonic epiploic appendages. Frequency of PEA is greater in the sigmoid colon, which is the place where appendix epiploica most commonly observed. Cecal PEA is seen rarely. PEA is actually a disease that can be cured by conservative treatment. However, cecal epiploic appendagitis is sometimes managed by surgical treatment because it mimics acute abdomen.

Case Reports: Two epiploic appendagitis cases were reported in this article. These patients were presented to our emergency department with sign and symptoms of acute appendicitis. Surgical treatment was performed in both two patients, since epiploic appendagitis was not radiologically identified in either case preoperatively

Conclusion: Surgery is not necessary in the treatment of epiploic appendagitis. A careful radiological examination, especially a computed tomography, would increase the correct diagnosis of epiploic appendagitis cases and provide an opportunity for conservative treatment. On the other hand, if cecal epiploic appendagitis can not be diagnosed preoperatively by the radiologist, surgery will be inevitable because it mimics acute appendicitis.

Keywords: Appendigitis, appendix epiploica, acute abdomen

\section{Özet}

Amaç: Primer epiploik apandajit (PEA), kolonik apendiks epiploikaların torsiyonu ya da spontan venöz trombozu sonucunda gelişen enflamatuar bir hastalıktır. PEA sıkı̆̆ı̆, apendiks epiploikaların en yaygın bulunduğu yer olan sigmoid kolonda fazladır. Çekal PEA nadiren görülür. PEA aslında konzervatif tedavilerle iyileşebilen bir hastalıktır. Ancak, çekal PEA bazen cerrahi olarak tedavi edilmektedir çünkü akut batını taklit etmektedir.

Olgular: Bu makalede iki epiploik apandajit olgusu sunulmaktadır. Bu hastalar acil servise akut apandisit belirti ve bulguları ile başvurmuşlardı. Her iki hastaya da cerrahi tedavi uygulandı çünkü ikisinde de preoperatif epiploik apandajit tanısı radyolojik olarak konulamamıştı.

Sonuç: Epiploik apandajit tedavisinde cerrahi gerekli değildir. Dikkatli bir radyolojik inceleme, özellikle bilgisayarlı tomografi, epiploik apandajit vakalarıın doğru teşhis edilmesini arttıracaktır ve konzervatif tedavi şansı sağlayacaktır. Öte yandan, akut apandisiti taklit eden çekal epiploik apandajit tanısı radyolog tarafından preoperatif konulamazsa, cerrahi kaçınılmaz olacaktır.

Anahtar Kelimeler: Apandajit, Apendiks epiploika, Akut batın 


\section{Giriş}

Apendices epiploicae are pedunculated formations that are developing in the 2 nd trimester of the fetal period. They present on the colon from cecum to sigmoid colon in two lines, each are measuring $0.5-5 \mathrm{~cm}$ in length and have a peritoneum covering. Their blood supply come from the branches of colic arteries. Their peduncles allow them move freely and set the stage for infarct development by becoming torsed ${ }^{1,2}$. Primary epiploic appendagitis (PEA) which is a self-limited inflammatory disease is rarely diagnosed clinically ${ }^{3}$. The twisting of the epiploica results in ischemic, initially with venous comprimise (low pressure) and the arterial occlusion ${ }^{4}$. This condition, defined as PEA, mimics surgical acute abdomen although it is not a pathology necessitating surgery.

\section{Case 1}

A 20-year-old male patient weighing $78 \mathrm{~kg}$, presented to the emergency room complaining of pain for 2 days localized at a point right of the umbilicus. Upon physical examination, bowel sounds were hypoactive and there was guarding and rebound tenderness in the right lower quadrant. He had a fever of 37.2 C with a leukocyte count of $12300 / \mu L$, with no nausea, vomiting or diarrhea. His laboratory tests were nonspecific. Abdominal ultrasonography (USG) demonstrated pericecal free fluid with no other pathology. The surgeon thought acute appendicitis and done laparotomy via McBurney insicion. Pericecal serous fluid with a torsed appendix epiploica was identified (Figure 1). There wasn't any other pathology. The ischemic appendix epiploica was excised.

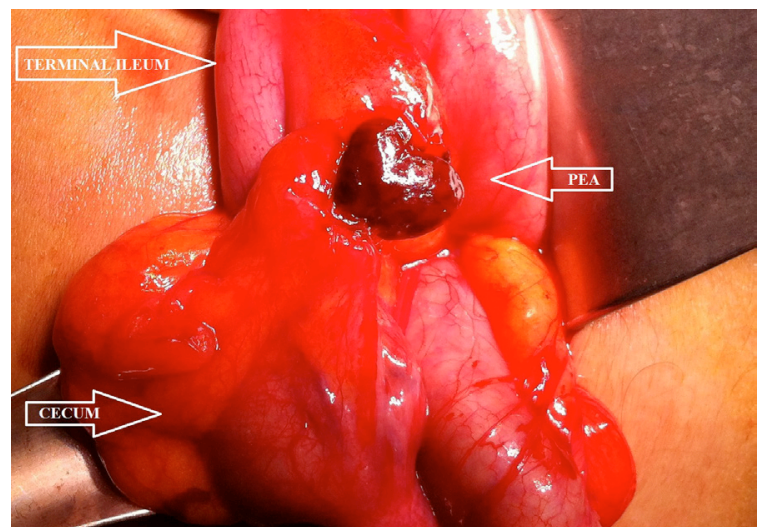

Figure 1: Case 1. Primary epiploic appendagitis

\section{Case 2}

An 18-year-old male patient weighing $65 \mathrm{~kg}$, presented to the emergency department complaining of pain for 3 days, which gradually increased in intensity and localized at a point in the right lower quadrant. Bowel sounds were hypoactive on physical examination, the right lower quadrant was guarding, and there was rebound tenderness. He had a fever of $37.7 \mathrm{C}$ with a leukocyte count of $11800 / \mu \mathrm{L}$, with no nausea, vomiting or diarrhea. There were no pathological findings in the abdominal ultrasonography. The appendix was $6 \mathrm{~mm}$ in diameter on the abdominal computed tomography (CT), and there was free fluid next to it. The patient underwent laparotomy for the diagnosis of acute appendicitis. Pericecal serous fluid with a torsed appendix epiploica neighboring the appendix was identified upon exploration (Figure 2). This necrotic appendix epiploica was excised and an appendectomy was done.

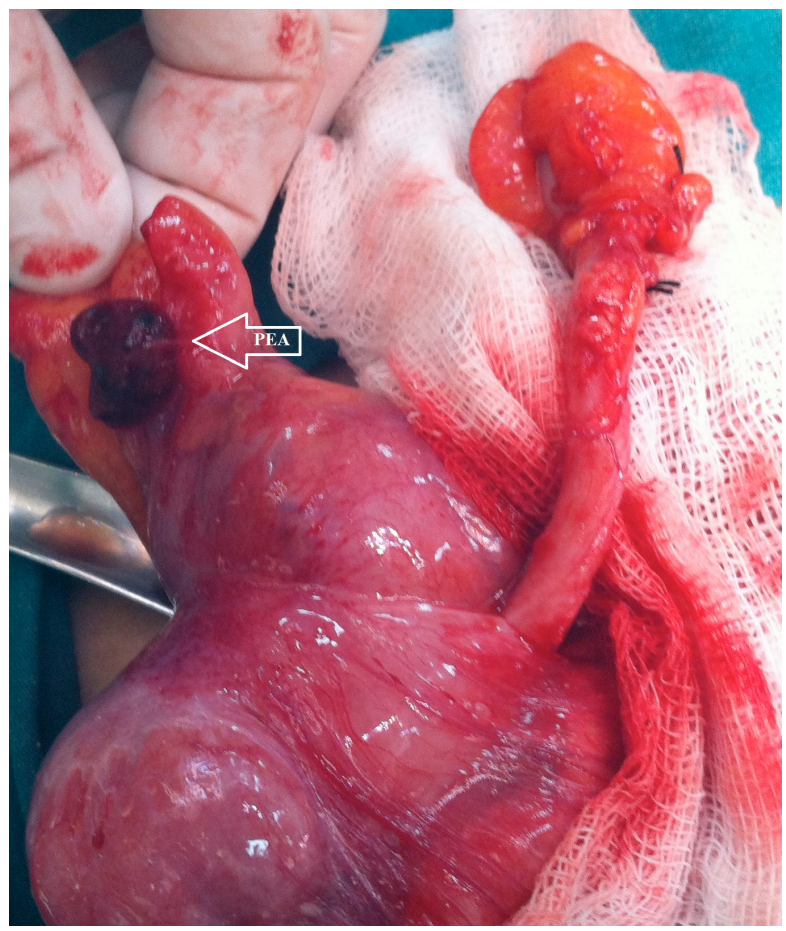

Figure 2. Case 2. View of cecal primary epiploic appendagitis

\section{Discussion}

PEA is seen more frequently in middle-aged males, though it can be seen in any age. Incidence of PEA is higher in the sigmoid colon, which is the place where appendix epiploica most 
commonly located $^{4-6}$. Cecal PEA is seen rarely ${ }^{7}$. The PEA cases that we encountered were seen in this less common location. The absence of radiological diagnosis of PEA and the presence of clinical signs of appendicitis, were effective in the decision for doing laparotomy. Although obesity and hernias are expressed as coexisting conditions with PEA in the literature, there was no such condition in our cases $^{8}$. Abdominal pain generally increases slowly, is also localized and constant. These patients rarely have gastrointestinal symptoms and only have pain. Clinical evaluations alone are not adequate to diagnose PEA. Acute appendicitis and acute diverticulitis are the first diseases that come into minds in such cases. Mis-diagnoses, as in our cases, are still frequently seen despite current imaging modalities. This makes us to believe that some cases with PEA presenting to emergency departments with abdominal pain are not diagnosed. A careful radiological examination is the key for diagnosis of PEA. It can be treated conservatively when it is diagnosed by noninvasive methods such as abdominal USG and/or CT. CT is diagnostic tool of choice and should have a high diagnostic accuracy. However, these patients generally are not diagnosed with noninvasive imaging methods.

A noncompressed, ovoid hyperechogeneous mass and a thin hypoechoic rim of fluid around it on USG, and no blood flow on doppler USG are the findings that can be identified. Currently, the diagnosis of PEA is easier with the use of $\mathrm{CT}^{9}$. PEA is observed through tomography as ovoid-shaped inflamed tissue in the dense fat, causing a thickening of the visceral peritoneum next to the colonic walls, and may be surrounded by fluid ${ }^{10}$. Some epiploic appendixes that fall to the peritoneal cavity might be encountered as free tissues at laparotomies ${ }^{11}$. Thomas et al was reported their own 11 cases and the review of 197 cases from the literature. They classified acute epiploic appendagitis according to their causes as torsion and inflammation (73\%), hernia incarceration (18\%), intestinal obstruction (8\%), and intraperitoneal loose body $(<1 \%)^{12}$. This is because each appendix epiploica has dual arterial blood flow, while it has only one venous drainage. Other conditions that might cause appendagitis epiploica are bacterial translocation developing secondary to diverticulitis and lymphoid hyperplasia $^{13,14}$

The diagnostic rate of USG was found as 58\% in a study by
Özdemir, et al, and it is stated that the diagnostic rate increases up to $70 \%$ with confirmation of the findings by CT. Therefore, the CT was expressed as a necessity in the diagnosis (4). Radiologically diagnosed PEA cases have been successfully treated by conservative methods. On the other hand, cases overlooked radiologically are directed to surgical procedures. Serous fluid at the site of the pathology seen during surgery might be a warning sign for the surgeon.

It is sometimes very difficult to diagnose an epiploic appendagitis radiologically. It depends on radiologists' experience. In our second case, preoperative CT examination was reported as acute apandicitis and free pericecal fluid. In the postoperative period, the abdominal CT's were re-examined by a blinded radiologist and reported as appendagitis epiploica. It's reported as epiploic appendagitis.

\section{Conclusion}

A progressive increase in abdominal pain in a constant localization and coexisting guarding, nonspecific laboratory findings, absence of fever or sub-febrile fever should raise suspicion for PEA. Clinical findings should be shared with radiologists. A careful radiological examination, especially a CT, would increase the correct diagnosis of these cases. Also it provides an opportunity for conservative treatment of patients with this condition. On the other hand, if cecal epiploic appendagitis can not be diagnosed by the radiologist, surgery will be inevitable because it mimics acute appendicitis. 


\section{References}

1. van Breda Vriesman AC, de Mol van Otterloo AJ, Puylaert JB. Epiploic appendagitis and omental infarction. Eur J Surg, 2001. 167(10): p. 723-7.

2. Platts-Mills TF, Burg MD. Epiploic appendagitis. J Emerg Med, 2009. 37(3): p.308-9.

3. Legome EL, Sims C, Rao PM. Epiploic appendagitis: adding to the differential of acute abdominal pain. J Emerg Med, 1999. 17(5): p. 823-6.

4. Ozdemir S, Gulpinar K, Leventoglu S,et al. Torsion of the primary epiploic appendagitis: a case series and review of the literature. Am J Surg, 2010. 199(4): p. 453-8.

5. Hasbahceci M, Erol C, Seker M. Epiploic appendagitis: is there need for surgery to confirm diagnosis in spite of clinical and radiological findings? World J Surg, 2012. 36(2): p. 441-6.

6. Mollà E, Ripollés T, Martínez MJ, et al. Primary epiploic appendagitis: US and CT findings. Eur Radiol, 1998. 8(3): p. 435-8.

7. Macari M, Laks S, Hajdu C, et al. Caecal epiploic appendagitis: an unlikely occurrence. Clin Radiol, 2008. 63(8): p. 895-900.
8. Ozkurt H, Karatağ O, Karaarslan E, et al. Clinical and CT findings of epiploic appendagitis within an inguinal hernia. Diagn Interv Radiol, 2007. 13(1): p. 23-5.

9. Boulanger BR, Barnes S, Bernard AC. Epiploic appendagitis: an emerging diagnosis for general surgeons. Am Surg, 2002. 68(11): p. 1022-5.

10. Singh AK, Gervais DA, Hahn PF, et al. CT appearance of acute appendagitis. Am J Roentgenol, 2004. 183(5): p. 1303-7.

11. Schein M, Rosen A, Decker GA. Acute conditions affecting epiploic appendages. A report of 4 cases. S Afr Med J, 1987. 71(6): p. 397-8.

12. Thomas JH, Rosato FE, Patterson LT. Epiploic appendagitis. Surg Gynecol Obstet1974; 138: 23-25.

13. Singh AK, Gervais DA, Hahn PF, et al. Acute epiploic appendagitis and its mimics. Radiographics, 2005. 25(6): p. 1521-34.

14. Vinson D.R. Epiploic appendagitis: a new diagnosis for the emergency physician. Two case reports and a review. J Emerg Med, 1999. 17(5): p. 827-32. 